\title{
Epidemiological Features of Rotavirus Infection in Goiânia, Goiás, Brazil, from 1986 to 2000
}

\author{
Divina das Dôres de Paula Cardoso/ ${ }^{+}$, Célia Maria Almeida Soares, Menira Borges de \\ Lima Dias e Souza, Marli da Silva Pereira de Azevedo, Regina Maria Bringel Martins, \\ Divina Aparecida de Oliveira Queiróz*, Wilia Marta Elsner Diederichsen de Brito, \\ Veridiana Munford**, Maria Lúcia Rácz**
}

\begin{abstract}
Laboratório de Virologia, Instituto de Patologia Tropical e Saúde Pública, Universidade Federal de Goiás, Rua Delenda Rezende de Melo esquina com $1^{\mathrm{a}}$ avenida s/n ${ }^{\circ}$, Setor Universitário, 74605-050 Goiânia, GO, Brasil *Laboratório de Virologia, Universidade

Federal de Uberlândia, Uberlândia, MG, Brasil **Departamento de Microbiologia, Instituto de Ciências Biomédicas, Universidade de São Paulo, São Paulo, SP, Brasil
\end{abstract}

A total of 2,605 faecal specimens from children up to 10 years old with or without diarrhoea were collected. Samples were obtained from 1986 to 2000 in hospitals, outpatient clinics and day-care centers in Goiânia, Goiás. Two methodologies for viral detection were utilized: a combined enzyme immunoassay for rotavirus and adenovirus and polyacrylamide gel electrophoresis. Results showed 374 (14.4\%) faecal specimens positive for Rotavirus A, most of them collected from hospitalized children. A significant detection rate of rotavirus during the period from April to August, dry season in Goiania, and different frequencies of viral detection throughout the years of study were also observed. Rotavirus was significantly related to hospitalization and to diarrhoeal illness in children up to 24 months old. This study reinforces the importance of rotavirus as a cause of diarrhoea in children and may be important in regards to the implementation of rotavirus vaccination strategies in our country.

Key words: rotavirus - gastroenteritis - epidemiology - seasonality - Goiás - Brazil

Diarrhoea is an important cause of morbidity in humans throughout the world, affecting mainly infants and children (Glass et al. 1996). Group A rotavirus is the most common cause of acute gastroenteritis in young children, causing a large number of hospitalizations (Pérez-Schael et al. 1999). Rotavirus is also associated with child mortality in several countries (Bern et al. 1992, Argüelles et al. 2000, Kapikian et al. 2001). This virus was detected for the first time in Brazil in 1976 (Linhares et al. 1977). After that description, several investigations were made and results demonstrated the relevance of rotavirus in the etiology of diarrhoea throughout the country (Rácz et al. 1988, Pereira et al. 1993, Leite et al. 1996).

This study presents results from a rotavirus surveillance in Goiânia, Goiás. Our analysis was focused on the role of the virus in the diarrhoeal illness, as well as on ageprevalence and seasonality of rotavirus infection in the region.

\section{MATERIALS AND METHODS}

Subject - The study was carried out in Goiânia, in the Central Region of Brazil. From March 1986 to December 1995, and from March 1998 to March 2000, 2,605 faecal specimens were collected from children up to 10 years of age. Specimens were obtained from children with or with-

Financial support: Laboratory Wyeth-Whitehall, Funape, CNPq and Fapesp.

${ }^{+}$Corresponding author: Fax: +55-62-202.3066. E-mail: divina@netgo.com.br

Received 7 May 2002

Accepted 16 October 2002 out diarrhoea from three different settings: children admitted to three hospitals (Hospital Materno Infantil, Hospital das Clínicas, and Hospital Lúcio Rebelo); children seen in outpatient clinics of Hospital Lúcio Rebelo, and children attending several day-care centers. Three or more liquid or semi-liquid daily evacuations were considered as diarrhoea, along with available medical information. Associated symptoms included vomit, fever and abdominal pain. The children enrolled in the study belonged to low socio-economic strata, according to the information provided by their parents/legal guardians. The faecal specimens were collected from the children only after a written consent was provided by parents/legal guardians. Also, ethical approval was obtained from the Ethics Committee on Research of the Federal University of Goiás.

Characteristics of the samples and of the children From 2,605 faecal specimens, 1,494 (57.4\%) were collected from hospitalized patients. Of the remainder faecal specimens, $528(20.3 \%)$ were obtained from children seen in outpatient clinics, and $583(22.4 \%)$ in day-care centers. The investigation in hospitals began in 1986 and continued until 2000, except for the 1995-1997 period, when no samples were collected. In outpatient clinics the collection of the faecal specimens took place from 1986 to 1995 , while in day-care centers samples were collected from 1989 to 1994 . From the total number of fecal samples, 1,324 $(50.8 \%)$ samples were collected from children with diarrhoea, and 1,246 (94.1\%) of these children were hospitalized. From the remaining samples, 1,281 (49.2\%) came from children who presented either with other symptoms than diarrhoea or with no symptoms. From those 480 (37.5\%) were from outpatient clinics. All children with no symptoms were from day-care centers. Regarding the gender 
of the children enrolled in the study, 1,387 (53.2\%) were male, and 1,218 (47.8\%) were female. Out of the total number of children studied $1,773(68.1 \%)$ were up to 24 months old and, of these, 1,309 were in hospitals, 201 in outpatient clinics and 263 in day-care centers.

Climatological characteristics - In Goiânia, during the period of the study, from April to August the monthly average temperature varied from 20.3 to $26.2^{\circ} \mathrm{C}$, the monthly average air relative humidity varied from 44 to $70 \%$ and the monthly average rainfall varied from 0 to $128.7 \mathrm{~mm}^{3}$. From September to March the monthly average temperature varied from 22.4 to $26.5^{\circ} \mathrm{C}$ and relative air humidity from 41 to $77.4 \%$ which were similar to April to August but the average of monthly rainfall were higher, ranging from 70.9-287.5 $\mathrm{mm}^{3}$ (data from Departamento Nacional de Água e Energia Elétrica; Companhia de Pesquisa e Recursos Minerais; Instituto Nacional de Meteorologia de Goiânia). In according to these institutions the period between April-August and SeptemberMarch corresponds to dry season and rainy season, respectively.

Viral detection - The faecal suspensions [20\% in phosphate buffered saline (PBS) pH 7.4] were analyzed by two methodologies: a combined enzyme immunoassay for rotavirus and adenovirus (EIARA) (Pereira et al. 1985), and polyacrylamide gel electrophoresis (PAGE) (Pereira et al. 1983).

Statistical analysis - The statistical significance of the data was examined by either chi-square test or by Fisher test and a probability of $<0.05$ was regarded as significant. Poisson distribution was also utilized when necessary.

\section{RESULTS}

Rotavirus A was detected in 374 (14.4\%) out of 2,605 faecal specimens. Of these samples, 356 were from hospitalized children. Comparison between rotavirus results from hospitalized $(23.8 \% ; 356 / 1,494)$ and non-hospitalized children $(1.6 \% ; 18 / 1111)\left(\chi^{2}=253.78 ; \mathrm{P}<0.0001\right)$ showed a relative risk of 14.71 times for hospitalization when rotavirus is present. Rotavirus-positivity in relation to presence of diarrhoea shows that this virus was more often detected in hospitalized children with diarrhoea $(27.8 \%$; $346 / 1,246)$ than in children without diarrhoea $(4.0 \% ; 10 /$ 248) $\left(\chi^{2}=62.9 ; \mathrm{P}<0.001\right)$. Similar results were found when comparing children from outpatient clinic with diarrhoea $(12.5 \% ; 6 / 48)$ when compared to children without diarrhoea $(1.7 \%$; 8/480) (Fisher test $\mathrm{P}=0.0007)$. In daycare center settings no statistical difference was observed (Fisher test $\mathrm{P}=0.19$ ).

According to the age of the children it was observed that, in hospitalized patients, rotavirus was detected with significantly higher frequency in children up to 24 months old $(25.7 \% ; 337 / 1,309)$, when compared to children older than 24 months $(10.3 \% ; 19 / 185)\left(\chi^{2}=4.25 \mathrm{P}<0.05\right)$. Also, rates of rotavirus detection among hospitalized children within the first year of life $(28.2 \% ; 227 / 806)$ were significantly higher than those for children in their second year of life $(21.9 \% ; 110 / 503)\left(\chi^{2}=6.53 \mathrm{P}<0.05\right)$. Similar results were found among children attending the outpatient clinics: rotavirus frequency was significantly higher in children up to 24 months $(5 \% ; 10 / 201)$ than in children older than 24 months $(2.7 \%$; 4/327) (Fisher test $\mathrm{P}=0.020)$. In day-care centers such a difference was not observed (Table I).

TABLE I

Distribution of rotavirus positive samples according to age-groups, symptomatology and place of collection, Goiânia, Goiás, 1986-2000

\begin{tabular}{|c|c|c|c|c|c|c|}
\hline \multirow{3}{*}{$\begin{array}{r}\text { Place/Age } \\
\text { (months) }\end{array}$} & \multicolumn{2}{|c|}{ Diarrhoea } & \multicolumn{2}{|c|}{ Other symptoms or no symptoms } & \multicolumn{2}{|c|}{ Total } \\
\hline & \multicolumn{2}{|c|}{ Rotavirus positive } & \multicolumn{2}{|c|}{ Rotavirus positive } & \multicolumn{2}{|c|}{ Rotavirus positive } \\
\hline & No. & $\%$ & No. & $\%$ & No. & $\%$ \\
\hline \multicolumn{7}{|l|}{ Hospital } \\
\hline $0-6$ & $101 / 326$ & 31 & $3 / 43$ & 7 & $104 / 369$ & 28.2 \\
\hline $7-12$ & $118 / 385$ & 30.6 & $5 / 52$ & 9.6 & $123 / 437$ & 28.1 \\
\hline $13-24$ & $109 / 402$ & 27.1 & $1 / 101$ & 1 & $110 / 503$ & 21.9 \\
\hline$>24$ & $18 / 133$ & 13.5 & $1 / 52$ & 1.9 & $19 / 185$ & 10.3 \\
\hline Total & $346 / 1,246$ & 27.8 & $10 / 248$ & 4 & $356 / 1,494$ & 23.8 \\
\hline \multicolumn{7}{|c|}{ Outpatient clinic } \\
\hline $0-6$ & $1 / 2$ & 50 & $0 / 9$ & 0 & $1 / 11$ & 9.1 \\
\hline $7-12$ & $0 / 8$ & 0 & $0 / 15$ & 0 & $0 / 23$ & 0 \\
\hline $13-24$ & $4 / 27$ & 14.8 & $5 / 140$ & 3.6 & $9 / 167$ & 5.4 \\
\hline$>24$ & $1 / 11$ & 9.1 & $3 / 316$ & 0.9 & $4 / 327$ & 1.2 \\
\hline Total & $6 / 48$ & 12.5 & $8 / 480$ & 1.7 & $14 / 528$ & 2.7 \\
\hline \multicolumn{7}{|c|}{ Day-care center } \\
\hline $0-6$ & $1 / 2$ & 50 & $0 / 13$ & 0 & $1 / 15$ & 6.7 \\
\hline $7-12$ & $0 / 5$ & 0 & $1 / 35$ & 2.9 & $1 / 40$ & 2.5 \\
\hline $13-24$ & $0 / 13$ & 0 & $0 / 195$ & 0 & $0 / 208$ & 0 \\
\hline$>24$ & $0 / 10$ & 0 & $2 / 310$ & 0.6 & $2 / 320$ & 0.6 \\
\hline Total & $1 / 30$ & 3.3 & $3 / 553$ & 0.5 & $4 / 583$ & 0.7 \\
\hline Total & $353 / 1,324$ & 26.7 & $21 / 1,281$ & 1.6 & $374 / 2,605$ & 14.4 \\
\hline
\end{tabular}


Rotavirus detection rates between genders showed 229 rotavirus positive out of 1,387 samples of male infants $(16.5 \%)$ and 145 out of 1,218 samples of female infants $(11.9 \%)$. This difference is statistiscally significant $\left(\chi^{2}=\right.$ 10.82; $\mathrm{P}<0.001)$.

Detection rates of rotavirus varied with month of sample collection throughout the study years. A significant difference was observed in the frequency of rotavirus detection in relation to the 374 positive faecal specimens: 301 out of 1,166 (25.8\%) samples were detected from April to August, dry season in Goiânia, while 73 out of 1,439 (5.1\%) were detected from September to March, corresponding to the rainy season $\left(\chi^{2}=226.06 ; \mathrm{P}<0.0001\right)$. These differences in detection rates between dry and rainy seasons were statistically significant for samples obtained from hospitals $\left(\chi^{2}=224.02 ; \mathrm{P}<0.001\right)$ and outpatient clin$\operatorname{ics}\left(\chi^{2}=3.96 ; \mathrm{P}<0.05\right.$ ), but not for day-care centers (not significant by the Poissson distribution) (Table II). (Data not shown in table).

Detection of rotaviruses among hospitalized children in different years showed a lower detection rate during the years of $1989(10.7 \%), 1990(17.6 \%)$ and $1994(14.5 \%)$. When the overall rainfall indexes for these years were considered, it was observed that during the years of 1989 and 1994 the low viral detection rates could be associated to a higher rainfall index and a higher relative air humidity (Table III).

\section{DISCUSSION}

In this study it was observed that $14.4 \%$ of the faecal specimens were positive for group A rotavirus (HuRVA). The analysis of rotavirus incidence in different set- tings showed that $23.8 \%$ of samples were rotavirus-positive in hospitalized children. Mohammed et al. (1994) found an overall rotavirus prevalence rate of $42.2 \%$ in Saudi Arabia, while in Brazil, prevalence rates ranged from 13 to $20 \%$ in different states (Pereira et al. 1993). Children from outpatient clinics showed only $2.7 \%$ of rotavirus-positive samples. Rotavirus infections are often more severe as well as more likely to be associated with dehydration and hospitalization (Coluchi et al. 2002). The proportion of children hospitalized for diarrhoea caused by rotavirus tend to be much higher than the proportion seen in outpatient clinics, as confirmed by our results and by other authors (Coluchi et al. 2002).

Rotavirus was detected in $26.7 \%$ of samples from children with diarrhoea, contrasting with the detection of $1.6 \%$ in children without diarrhoea. These results are similar to those described by other authors in Brazil (Rácz et al. 1988, Orlandi et al. 2001) or in other countries (Brandt et al. 1979, Chakravarti et al. 1992)

Rotavirus was found in higher proportion in male when compared to female children. These data are similar to reports by some authors (Chakravarti et al. 1992, Espinoza et al. 1997), even though others did not find a significant difference in rotavirus frequencies between genders (Brandt et al. 1979, Pérez-Schael et al. 1999).

Rotavirus gastroenteritis severe enough to require hospitalization characteristically occurs most frequently in infants and young children from approximately 6 months to 2 years of age (Kapikian et al. 2001). In this study, it was observed a high detection rate of rotavirus among children up to 24 months of age. Viral detection was also more frequent among hospitalized children within the first year

TABLE II

Frequency of rotavirus detection according to two different climatological seasons in Goiânia, Goiás, Brazil

\begin{tabular}{|c|c|c|c|c|c|c|c|c|}
\hline \multirow{3}{*}{$\begin{array}{l}\text { Climatological } \\
\text { season }\end{array}$} & \multicolumn{2}{|c|}{ Hospital } & \multicolumn{2}{|c|}{ Outpatient clinic } & \multicolumn{2}{|c|}{ Day-care center } & \multicolumn{2}{|c|}{ Total } \\
\hline & \multicolumn{2}{|c|}{ Rotavirus positive } & \multicolumn{2}{|c|}{ Rotavirus positive } & \multicolumn{2}{|c|}{ Rotavirus positive } & \multicolumn{2}{|c|}{ Rotavirus positive } \\
\hline & No. & $\%$ & No. & $\%$ & No. & $\%$ & No. & $\%$ \\
\hline Dry & 290/701 & 41.4 & $11 / 258$ & 4.3 & $0 / 207$ & 0 & $301 / 1,166$ & 25.8 \\
\hline Rainy & $66 / 793$ & 8.3 & $3 / 270$ & 1.1 & $4 / 376$ & 1.1 & 73/1,439 & 5.1 \\
\hline
\end{tabular}

TABLE III

Relationship between rotavirus detection in the hospitalized population and climatological data, 1986-1999

\begin{tabular}{|c|c|c|c|c|c|c|}
\hline \multirow[b]{2}{*}{ Year $^{a}$} & \multirow{2}{*}{$\begin{array}{l}\text { No. of } \\
\text { samples }\end{array}$} & \multicolumn{2}{|c|}{ Rotavirus positive } & \multirow{2}{*}{$\begin{array}{c}\text { RU } \\
\%\end{array}$} & \multirow{2}{*}{$\underset{{ }^{\circ} \mathrm{C}}{\text { Temp. }}$} & \multirow{2}{*}{$\begin{array}{c}\mathrm{RI} \\
\mathrm{mm}^{3}\end{array}$} \\
\hline & & No. & $\%$ & & & \\
\hline 1986 & 152 & 45 & 29.6 & 62.8 & 24.2 & $1,438.8$ \\
\hline 1987 & 199 & 66 & 33.2 & 63.2 & 24.7 & $1,588.7$ \\
\hline 1988 & 94 & 26 & 27.7 & 62.2 & 24.6 & $1,618.4$ \\
\hline 1989 & 225 & 24 & 10.7 & 66.3 & 23.7 & $1,747.5$ \\
\hline 1990 & 108 & 19 & 17.6 & 61.8 & 23.6 & $1,209.5$ \\
\hline 1992 & 49 & 13 & 26.5 & 65.6 & 23.2 & $1,790.7$ \\
\hline 1993 & 91 & 34 & 37.4 & 61.1 & 22.8 & $1,179.1$ \\
\hline 1994 & 55 & 8 & 14.5 & 79.7 & 22.5 & $1,612.9$ \\
\hline 1998 & 175 & 40 & 22.9 & 60.8 & 24.9 & $1,002.2$ \\
\hline 1999 & 295 & 81 & 27.5 & 60.7 & 24.5 & $1,188.0$ \\
\hline
\end{tabular}

$a$ : the years of 1991 (5 samples, all negative) and 2000 (46 samples, all negative) were excluded due to the small number of specimens collected. In 2000 the collection of the faecal specimens was interrupted in March; RU: annual mean relative humidity; Temp.: annual mean temperature; RI: annual mean rainfall index 
of life. In Australia, rotavirus gastroenteritis was also more often observed among hospitalized children in the under 6-month age group, although at lower rate $18.7 \%$, than ours (Barnes et al. 1998). In children older than 6 months, the detection rates of rotavirus tend to increase until the age of 24 months (Kapikian et al. 2001). Our results shows that frequencies of rotavirus positive samples are comparable between age groups up to 12 months, tended to decrease in the second year of life and decreased markedly in the group of children older than 2 years. These results are similar to those described in Venezuela (PérezSchael et al. 1999) but differs from results obtained recently in Paraguay (Coluchi et al. 2002).

In outpatient clinics and in day-care centers, rotavirus positivity rates found in this study are lower than those reported by others. Keswick et al. (1983) found 2.4\% of children without diarrhoea from day-care center to be positive for rotavirus; Rácz et al. (1988) found $15.8 \%$ rotavirus positivity in children attending outpatient clinics. Age seems to be related to the low frequency of rotavirus detection in those patients and also for the absence of rotavirus outbreaks in day-care centers. Indeed only $6.3 \%$ of children from outpatient clinics and $9.5 \%$ from day-care center were up to 12 months old. We also consider that the age could have accounted for the nonsignificant statistical difference between rotavirus detection rates in diarrhoeic and non-diarrhoeic children from day-care centers.

Rotaviruses display a seasonal pattern of infection in developed countries, with epidemic peaks occurring in the cooler and driest months of each year; this usual seasonal pattern of rotavirus infection observed in the temperate climates does not occur uniformly in other settings (Kapikian et al. 2001). In our study, rotavirus infections were found to be more prevalent during the period of April to August. In Brazil, there are different frequencies of rotavirus detection throughout the year. In several regions of Brazil, as in the Southern region, a peak incidence was observed, mostly during winter months (Pereira et al. 1993); in Rio Grande do Sul, also in Southern region, a higher incidence of rotavirus infection was observed during the summer months (Coiro et al. 1983). In most states in the Northern region of the country, with tropical climates, seasonality has not been observed (Pereira et al. 1993). Our results are similar to some of those obtained for the Northeastern region, where a higher frequency of rotavirus was observed from June to October, which corresponds to the dry season in that region (Guerrant et al. 1983). In our study, seasonality could be correlated to the low relative atmospheric air humidity that, during the dry season, reaches 47 to $50 \%$, which is considered a good condition for rotavirus survival (Sattar et al. 1984).

Rotavirus frequency showed variations throughout the years of the study. The lowest rotavirus detection rate occurred in 1989, whereas the highest one was seen in 1993. Frequency of rotavirus detection showed a cyclic pattern of occurrence. Years with high frequency of rotavirus identification, like 1993 (37.4\%), were followed by a low frequency in the next year $(14.5 \%)$. This result could indicate that, if a high proportion of children were infected in one year, there is lower numbers of suscep- tible children to be infected in the next year because infection could have generated a high immunity against rotavirus in the population. This suggestion seems be reinforced due to the fact that in our region the circulation of G serotypes is mutually exclusive, at least for G1 and G2. In this way from 1987 to 1989 G1 serotype was prevalent and then, in 1990, it was replaced by G2 serotype. This serotype was prevalent until 1993 when it was replaced by G1 serotype again (Cardoso et al. 2000). Analysis of the yearly occurrence results in Washington, D.C., USA shows similarities to our results (Brandt et al. 1983). Analysis of the average annual mean of relative humidity (RU) and of index of rainfall (RI) during the years of the study shows that these variables could also be linked to the highest and lowest rotavirus incidence rates. In 1993, a high percentage (37.4\%) of samples was positive for rotavirus, while relative humidity and rainfall index were low $\left(61.1 \%\right.$ and $\left.1,179.1 \mathrm{~mm}^{3}\right)$. In contrast, in the years 1989 and 1994, low frequency of rotavirus was found, corresponding to a high RU and RI. In conclusion, the frequencies of rotavirus detection in different years could be related to both prevalence of a determined G serotype and to the climatological conditions during that particular year.

We consider that regional epidemiological information about rotavirus infections in developing countries may be important in the implementation of rotavirus vaccination strategies in Brazil.

\section{ACKNOWLEDGEMENTS}

To the Fundação Oswaldo Cruz for providing the reagents used in the Combined Enzyme Immunoassay for Rotavirus and Adenovirus technique.

\section{REFERENCES}

Argüelles MH, Villegas GA, Castello A, Abrami A, Ghiringhelli PD, Semorile L, Glikmann G 2000. VP7 and VP4 genotyping of human group A rotavirus in Buenos Aires, Argentina. $J$ Clin Microbiol 38: 252-259.

Barnes GL, Uren E, Stevens KB, Bishop RF 1998. Etiology of acute gastroenteritis in hospitalized children in Melbourne, Australia, from april 1980 to march 1993. J Clin Microbiol 36:133-138.

Bern C, Unicomb LE, Gentsch JR, Banul N, Yunus M, Sack RB, Glass RI 1992. Rotavirus diarrhea in Bangladeshi children: correlation of disease severity with serotypes. J Clin Microbiol 30: 19203-3238.

Brandt CD, Kim HW, Rodriguez WJ, Arrobio JO, Jeffries BC, Stallings EPL, Miles AJ, Chanock RM, Kapikian AZ, Parrott RH 1983. Pediatric viral gastroenteritis during eight years of study. J Clin Microbiol 18: 71-78.

Brandt CD, Kim HW, Yolken RH, Kapikian AZ, Arrobio JO, Rodriguez WJ, Wyatt RG, Chanock RM, Parrott RH 1979. Comparative epidemiology of two rotavirus serotypes and other viral agents associated with pediatric gastroenteritis. Am J Epidemiol 110: 243-254.

Cardoso DDP, Soares CMA, Azevedo MSP, Leite JPG, Munford V, Rácz ML 2000. Serotypes and subgroups of rotavirus isolated from children in Central Brazil. J Health Popul Nutr 18: 39-43.

Chakravarti A, Kumar S, Mittal SK, Broor S 1992. Clinical and epidemiogical features of acute gastroenteritis caused by human rotavirus subgroups. J Diar Dis Res 10: 21-24.

Coiro JRR, Bendati MMA, Almeida Neto AJ, Heuser MCF, 
Vasconcellos VL 1983. Rotavirus infection in Brazilian children with acute enteritis: a seazonal variation study. $A m \mathrm{~J}$ Trop Med Hyg 32: 1186-1188.

Coluchi N, Munford V, Manzur J, Vazquez C, Escobar M, Weber E, Mármol P, Rácz ML 2002. Detection, subgroup specificity and genotype diversity of rotavirus strains in children with acute diarrhea in Paraguay. J Clin Microbiol 40: in press.

Espinoza F, Paniagua M, Hallander H, Hedlund KO, Svensson L 1997. Prevalence and characteristics of severe rotavirus infections in Nicaraguan Children. Ann Trop Paediatr 17: 25-32.

Glass RI, Lang DR, Ivanoff BN, Compans RW 1996. Introduction: Rotavirus - from basic research to a vaccine. J Infect Dis 174: S1-S2.

Guerrant RL, Kiiiirchhoff LV, Shields DS, Nations MK, Leslie J, Souza MA, Araujo JG, Correia LL, Sauer KT, McClelland KE, Trowbridge FL, Hughes JM 1983. Porspective study of diarrheal illnesses in Northeastern Brazil: patterns of disease, nutritional impact, etiologies and risk factors. $J$ Infect Dis 148: 986-997.

Kapikian AZ, Hoshino Y, Chanock RM 2001. Rotaviruses. In DM Knipe, PM Howley (eds), Fields Virology, Lippincott Williams \& Wilkins, Philadelphia, p. 1787-1833.

Keswick BH, Pickering LK, Dupont HL, Woodward WE 1983. Prevalence of rotavirus in children in day care centers. $J$ Pediatr 103: 85-86.

Leite JPG, Alfieri AA, Woods PA, Glass RI, Gentsch JR 1996. Rotavirus $\mathrm{G}$ and $\mathrm{P}$ types circulation in Brazil: characterization by RT-PCR, probe hybridization, and sequence analysis. Arch Virol 141: 2365-2374.

Linhares AC, Pinheiro FP, Schmetz C, Muller G, Peters D 1977. Duovirus (rotavirus) em Belém do Pará, Brasil (nota prévia). Rev Inst Med Trop São Paulo 19: 278-279.

Mohammed KA, Assouli SME, Baanjar Z 1994. Human rotavirus subgroups and serotypes in children with acute gastroenteritis in Saudi Arabia from 1988 to 1992. J Med Virol 44: 237-242.

Orlandi PP, Silva T, Magalhães GF, Alver F, Cunha RPA, Durlacher R, Silva LHP 2001. Enteropathogens associated with diarreal disease in infants of poor urban areas of Porto Velho, Rondônia: a preliminary study. Mem Inst Oswaldo Cruz, 96: 621-625.

Pereira HG, Azeredo RS, Leite JPG, Andrade ZP, Castro L 1985. A combined enzyme immunoassay for rotavirus and adenovirus. J Virol Meth 10: 21-28.

Pereira HG, Azeredo RS, Leite JPG, Candeias JAN, Rácz ML, Linhares AC, Gabbay YB, Trabulsi LR 1983. Electrophoretic study of the genome of human rotaviruses from Rio de Janeiro, Sao Paulo and Pará, Brazil. J Hyg Camb 90: 117-125.

Pereira HG, Linhares AC, Candeias JAN, Glass RI 1993. National laboratory surveillance of viral agents of gastroenteritis in Brazil. Bul PAHO 27: 224-233.

Pérez-Schael I, González R, Fernández R, Alfonso E, Inaty D, Boher Y, Sarmiento L 1999. Epidemiological features of rotavirus infection in Caradas, Venezuela: implications for rotavirus immunization programs. J Med Virol 59: 520-526.

Rácz ML, Candeias JAN, Trabulsi LR, Murahowsky J 1988. Diarrheal diseases in Brazil: clinical features of rotavirusassociated gastroenteritis in children. Eur J Epidemiol 4: 382-385.

Sattar SA, Ijaz MK, Johnson-Lussenburg CM, Springthorpe VS 1984. Effect of relative humidity on the airborne survival of rotavirus SA11. Appl Environ Microbiol 47: 879881. 